\title{
Using SWOT to Analyze the Advantages and Disadvantages of China's Implementation of "Business Tax to VAT" Policy
}

\author{
Qin Yue \\ Dongbei Finance and Economics University \\ Liao Ning, China
}

\author{
Mingxi Peng \\ Dalian Polytechnic University \\ Liao Ning, China \\ 1791277258@qq.com
}

\begin{abstract}
The implementation of VAT reduced the tax burden of enterprises and ensured the state's tax security. But there are still some political issues that need to be solved in the process of policy implementation. This paper uses SWOT analysis method to analyze the advantages and disadvantages existing in the process of tax reform, and puts forward a series of suggestions.
\end{abstract}

Keywords-SWOT analysis; business tax reform; value-added tax; political issues

\section{INTRODUCTION}

The executive meeting of the State Council held in China in March 18, 2016, deciding to carry out the pilot work of replacing business tax with value-added tax, "business tax to VAT" for short, in China on May 1, 2016. At this point, the business tax was completely withdrawn from the historical stage. 'business tax to VAT' exerted huge impact on China.

"Business tax to VAT" is one of the most important tax reforms in China. Chinese scholars have conducted some research on it. Zhiwei Tian and Yijian Hu (2014) used the dynamic CGE model to study the different effects of VAT "7+1" expansion on industrial taxation and macroeconomics in different industrial sectors at different stages [1]. Ziying Fan and Fei Peng (2017) used the Triple difference model to assess the impact of "business tax to VAT" on reductions of corporate tax and Web Service Technology, and concluded that business tax has produced a significant effect of tax reduction on enterprises with industrial interconnection.[2] . Jinjiang Fan (2016) used Propensity Score Match to analyze the reasons for the increase in corporate circulation tax after China's 'business tax to VAT", and proposed a certain resolutions [3].

Most of the previous articles are result-oriented articles, and they are studied from the direction of the results caused by the tax reform. This article pays attention to the objectives and process of tax reform, and tries to discuss the advantages and disadvantages of "business tax to VAT" in China through the SWOT analysis method.

\section{SCEnARIO SETtings ABOUt the SWOT MODEL}

The SWOT analysis matrix consists of four components: internal strength (S), weak (W), external (opportunity), and threat (Treat). This paper makes certain adjustments to the model. On the one hand, "business tax to VAT" is internal reforms, and external factors have limited intervention. On the other hand, tax reform is mainly affected by the secondary and tertiary industries. Therefore, the internal factors in this article refer specifically to the government itself, while the external factors are defined as the industrial environment, which is formed by the second and third types of industries in China. The external opportunities of the original model are defined as the advantages of the external industrial environment and uses $O_{e n}$ to represent; and the threats to the external industrial environment use $T_{e n}$ expressed.

\section{UtILIZING THE SWOT MoDEL TO ANALYZE THE Advantages AND DisAdVANTAgES OF TAX REFORM IN CHINA}

A. The advantages within the government mainly exist in:

1) The concentration of government rights and strong political mobilization: China implements a centralised, top-down political management system. The central government has the highest power to make decisions. Local government needs to follow the instructions from the central government. Although local governments have a certain autonomy, they must use their rights under the macroeconomic policies of the central government. That means the relationship, between the central government and the local government, has become the direct management method, which shows that all policies are formulated and implemented by the central government. This institutional feature protects the implementation of the policy effectively, and helps the central government to make the unified layout of China, according to its conditions.

2) The internal pluralism: Unlike the multi-party system of Western countries, China implements a one-party governance approach. In order to ensure that the interests of different hierarchy can be guaranteed, the ruling party in China adopts a multiple and internal approach to meet the requirements of political participation of different interest groups [6]. Since reform and opening-up, the rise of the middle class has become the most obvious feature of Chinese society. The growing middle class in China shows strong demands for political participation. This is why China 
continuously strengthens the constitutional protection of non-state-owned enterprises and encourages private enterprises to participate in politics.

3) Strong learning and error correction: The Chinese government has showed a strong ability to learn and correct mistakes during its governance. After becoming a ruling party in China, the Communist Party of China continuously improved its own ability of problem-solving. Although there are some decisions that are out of reality and blindly developed in the process of governing ,they can be corrected in a timely manner. After China's reform and opening-up, China has accelerated its integration into the world. Through learning advanced Western technologies and management methods, combined with its own social characteristics, China has greatly accelerated the pace of catching up with the world.

4) Political independence: China is an independent and sovereign country with complete sovereignty. It does not interfere with the external factors of other countries in formulating its policy guidelines. Therefore, it can fully consider the characteristics of its own national conditions in the process of formulating policies.

5) Perfect talent selection and training mechanism: Talents are the foundation of a country and a society. China has established a top-down and perfect talent selection and training mechanism. In the selection of ordinary civil servants, China conducts regular civil service examinations in the nationwide each year. Provinces and municipalities also independently organize recruitment of personnel according to their respective circumstances. In terms of political elites, the leadership retirement mechanism, proposed by Deng Xiaoping, has accelerated the replacement of political talents, safeguarded the replacement speed of elites, and provided space for the rise of the personnel of other classes. Governments at all levels regularly organize regular learning at all levels of the organization, fully guaranteeing the breadth, timeliness, and professionalism of member knowledge.

6) The need for industrial upgrading: According to China's gross domestic product statistics for the first quarter of 2017, the proportions of China's three industries were: $4.79 \%$, 38.74\%, and $56.47 \%$ respectively. The proportion of the service industry in Western developed countries has reached more than two-thirds, and China still needs to adjust its own industrial structure. Although China is a large manufacturing country, there are still many problems, such as insufficient innovation capacity, declining cost advantages, and low value-added products. [4] At the same time as the rapid development of the tertiary industry, the gap between the tertiary industry and the modern service industry has gradually emerged. Industrial upgrading has become an urgent and urgent task for China.

\section{B. The disadvantage of the government lies in:}

1) Lacking autonomy of local governments: The negative side of China's centralization is the lack of local government autonomy. When the central government formulates a unified national development policy, it is impossible to consider all aspects. The lack of local government's autonomy will lead to incompatibilities during the implementation of the policy.

2) The negative influence caused by the official performance evaluation system: Official performance evaluation system is an important assessment factor related to the fate of officials. Therefore, when local officials implement relevant policies formulated by superiors, they often consider the satisfaction of their superiors. That has also led to the short-sighted nature of local officials. An official only needs to consider the approval of the higher authorities within his term of office, without considering the problems left over from promotion.

3) Feedback delay: There is a time lag between the implementation of the policy and the emergence of the problem. For example, it will cost a long time to judge whether a new policy generate some bad influences. At the same time, when local governments receive feedback from companies, they also need to speed time to sort out and investigate the issues. Only those issues that are defined by local governments as widespread and serious issues will be fed back to higher levels of government. This may lead to delays or even distortions in the information feedback.

4) Local governments ignore the appeals of enterprises: According to the Constitution and the Organic Law, the local government's administrative system has implemented a double responsibility system, that means local governments are responsible to both the superior government and the people's congress. Although different levels of governments have provided enterprises with corresponding channels for appeals, there are no mandatory measures to ensure that local governments can truly focus on the company's demands and solve them effectively. Local governments emphasis mainly the judgement of higher-level governments instead of whether they can take into account the interests of all groups.

5) Transparency of Policy Implementation: Improving the transparency of policies and their formulation process are effective way to ensure the right to know of public, reduce the asymmetry of policy information, increase the rationality of policies, and reduce the random measures of making policies. Compared with the past, the transparency of China's policies has been improved to some extent. The government-owned departments and their think tanks often hold press conferences, which has become an important way for the public to understand China's policy decisions. However, in the course of the implementation of the policy, China' government still lacks of deeply explanation of the policy, and some answers to some questions are rather vague.

\section{External industrial environment opportunities:}

1) Demand for fair competition by enterprises: The fairness of taxation mainly includes two aspects. On the one hand, the national taxation should be compatible with the individual taxpayer's ability. On the other hand, the taxpayer's burden level is balanced. The former mainly refers to 
collecting the same amount of tax from taxpayers, those who have the same economic strength, and the latter refers to collecting different amounts of taxes from taxpayers with different economic strengths. Business tax lacks of taxation inertia, because it does not have deduction effect. In order to reduce costs, some enterprises have chosen to import raw materials to some illegally-run enterprises and have reduced their costs, That has resulted in unfair competition.

2) The need for enterprises to avoid duplicate taxation: Business tax is mainly levied on turnover. When a company imports raw materials from upstream enterprises, the price it buys not only includes the raw material production cost, but also includes the transfer tax burden from upstream corporate. This phenomenon eventually led to the problems that company must takes up multiple business tax, which are coming from the upstream company. There is a deductible benefit from VAT that can be used to offset the taxation from higher level to avoid duplicate taxation and reduce corporate burden.

3) Demand for specialized division of labor: The specialized production of enterprises has many advantages. For example, improving the work proficiency of personnel, saving working hours, reducing the cost of personnel recruitment and training. Specialized division of labor is an inevitable choice for companies to reduce production costs and pursue higher profits. However, the traditional taxation method has hindered the professional division of labor of enterprises. Some companies choose to develop their upstream or downstream links in order to reduce the tax burden, thus forming a vertical monopoly. It is not conducive to the development of specialized division of labor. [5]

4) The need for enterprises to improve their management level: Due to historical reasons, Chinese private enterprises developed lately. Lacking concentration on corporate management has resulted in a poor standardization in Chinese business management and has affected the long-term development of enterprises. The "business tax to VAT" imposes higher requirements on the management of enterprises. Under the new tax policy, enterprises must seek higher profits by standardizing their own management models, clarifying the direction of development of enterprises, and improving the level of management personnel, and making scientific decisions to improve the management level of the company.

\section{External industrial environment threats:}

1) The increasing tax burden in individual industries: Taking the transportation industry as an example, the major components of the transportation industry are oil cost, crossing cost of bridges, labor costs, and housing rent. Among them, fuel costs that are the major cost of transportation industry issue ordinary invoices, which cannot be used as a tax deduction. The remaining expenses of transportation industry are not included in the input tax, either. After "business tax to VAT", the tax rate of the transport-trafficking industry rose from $3 \%$ to $11 \%$, and the excessively high tax rate brings more burden to the company. [6]

2) Increased financial burden on the company: When ran business tax system, the financial department of the company only needed the net income and tax rate to calculate the tax. Nowadays, VAT's calculation is more complex than the business tax. For example, an enterprise should distinguish input tax and output tax. If the financial department can not calculate which part of raw materials can be seen as input tax, they will result in the lose of company. VAT ask company to make adjustments to its accounting review.

3) Difficulties in obtaining useful offset invoices: It is difficult for some industries to obtain useful invoices for deductions. For example, in the field of construction industry, suppliers of some raw materials cannot provide valid invoice vouchers, which increases the tax burden on the construction industry. When invoices are issued, some types of invoices cannot be deducted, for example, invoices issued from passing bridges that account for a large portion of the cost in the transportation industry. Finally, not all input tax for VAT invoices can be deducted, and some non-compliant invoices, such as abnormal loss of purchased goods and related services, cannot be deducted.

4) Increasing costs of non-standard enterprises: In order to save costs, some companies often purchase low-priced raw materials from companies that cannot issue invoices. This phenomenon makes regular production enterprises at a disadvantage in competition. Through the deduction effect of VAT, the company's production chain form a set of supervision system to curb the illegal behavior of some enterprises. That also result in losses for companies that are not regulated.

\section{Suggestions for Solving Problems IN the PROCESS OF "BUSINESS TAX TO VAT":}

\section{A. Strengthen the guidance of the company:}

The issuance of new tax policies inevitably cause enterprises use more energy to adapt. Government can guide enterprises in a certain way and shorten their lost time. Government has various ways to help enterprises to accept new policy: Firstly, administrative guidance, which is a unique method for the guidance of enterprises in East Asian countries. Administrative guidance is an indirect intervention measures based on the mutual consultation between the government and the enterprise. The methods mainly include personnel appointment and dismissal, procedure control, assessment and evaluation, persuasion and negotiation, orders, information exchange, publicity call, etc. However, administrative guidance measures do not have legal effect. Secondly, information guidance: When enterprises make decisions, they need a lot of external information. The government can guide the company's behavior by providing information. 


\section{B. Strengthen the communication between the central government, local governments and enterprises:}

China has many methods of communication between the government and the enterprise. For example, representatives of National People's Congress who are elected by the company is one of the way that enterprises deliver their demands to government. However, during the tax reform, this kind of single communication method is difficult to timely and comprehensively reflect the problems faced by different companies during the period of "business tax to VAT", it requires establishing a more efficient mechanism for communication between enterprises and governments. That can not only reduce the resistance of enterprises in the process of tax reforms, but also can find the problems in the tax reform process and correct them, timely.

\section{Simplification and standardization of invoices:}

The current invoices in China mainly include general invoices and professional invoices. The invoices used for value-added tax are the second one, which shows how to deduct taxes. It is difficult for some industries to obtain valid VAT invoices. That has caused an increase in the tax burden of some industries. The government can simplify the types of invoices and gradually implement the electronic invoice system, which can bring more convenience and reduction of cost to company.

\section{Adjust the proportion of taxes in different industries:}

According to research conducted by some Chinese scholars, the tax burden of most industries has been reduced after
China's "business tax to VAT". However, some industries such as transportation, telecommunications, resident services, and other service industries experience a rise of tax revenue. That requires government to adjust the taxation of these industries to ensure that different industries can enjoy the benefits in the process of "business tax to VAT", thus promoting the balanced development of different industries.

\section{REFERENCES}

[1] Ivana Beveridge, Johannes Kadura, Andreas Stratemeyer. Chapter 9 - A New FDI Framework in the Chinese Services Industry [M]. Elsevier Ltd:2017-06-15.

[2] Announcement on clarifying certain business tax issues [J]. CPA, 2016(02):80. (In Chinese)

[3] MA Xin. A brief analysis of contemporary Chinese political "characteristics" in terms of institutions [J]. Journal of the Yunnan Communist Party College of CPC, 2017, 18(01):152-158. (In Chinese)

[4] Nie Minghua, Xu Yingjie, Liu Taoxia. Reverse Technology Spillover of Foreign Direct Investment and China's Industrial Structure Upgrading [J]. Guizhou Social Sciences, 2017(05): 95-102. (In Chinese)

[5] Fan Ziying, Peng Fei. The tax reduction effect and division of labor effect of "reform by business reform": Based on the perspective of industry interconnection [J]. Economic Research, 2017, 52(02): 82-95. (In Chinese)

[6] Liang Yunfeng, Wang Ning. Study on the Influence of "Camp Restructuring Increase" on the Industrial Development and Macroeconomic Status of Beijing-Based on the Analysis of CGE Model[J]. Journal of Central University of Finance and Economics, 2016(07):24-31. (In Chinese) 